\title{
The mechanism of protection of infant mice from intestinal colonisation with Campylobacter jejuni
}

\author{
ALASH'LE G. ABIMIKU and JEAN M. DOLBY \\ Division of Communicable Diseases, MRC Clinical Research Centre, Watford Road, Harrow, Middlesex \\ HA1 3UJ
}

\begin{abstract}
Summary. BALB/c mice, vaccinated intraperitoneally with a heat-killed $\left(62^{\circ} \mathrm{C}\right)$ suspension of Campylobacter jejuni before mating, completely protect $c .90 \%$ of their own infants from intestinal colonisation. This protection has now been investigated further in fostering experiments. Fostering by vaccinated dams within the first $24 \mathrm{~h}$ of life prevented intestinal colonisation in $50 \%$ of infants from non-vaccinated dams, and reduced colonisation in a further $25 \%$. Infants from vaccinated dams, even if allowed to receive their own mothers' colostrum and milk, became susceptible to challenge when subsequently fostered by non-vaccinated dams. Immunity in experimentally infected infant mice depended upon the consumption of immune milk at and after the time of challenge. High concentrations of IgG antibodies specific for $C$. jejuni were found in the serum and mammary secretion of vaccinated dams, but there was very little specific IgA antibody.
\end{abstract}

\section{Introduction}

Campylobacter jejuni infection is a common cause of diarrhoea that is usually self-limiting and of varying severity in children and adults (Butzler and Skirrow, 1979). It can cause death in the elderly and the debilitated and severe chronic infection in immunodeficient patients (Ahnen and Brown, 1982). The pathogenesis of campylobacter-induced disease is not clear (Klipstein et al., 1985; Taylor et al., 1985). Little is known about protective mechanisms, but the immune responses, mainly antiflagellar, have been described (Kaldor et al., 1983; Wenman et al., 1985).

An ideal animal model of the disease is not available, but after oral infection the alimentary tract of infant mice becomes colonised without giving rise to illness (Field et al., 1981). Protection against this colonisation can be produced by vaccinating the females before mating (Dolby and Newell, 1986). Like other intestinal bacterial pathogens, $C$. jejuni adheres to mucosal surfaces (Newell and Pearson, 1984; Fauchère et al., 1985) and it seems likely that protection in the infant mouse is brought about by interference with adherence and hence with colonisation. Flagella, although aiding colonisation (Newell et al., 1985), apparently play little role in stimulating protection

Received 17 Jul. 1986; accepted 5 Sep. 1986. against colonisation in the infant mouse, because a non-flagellate variant effectively immunised against the flagellate parent strain (Dolby and Newell, 1986).

The purpose of this study was to examine, by means of fostering experiments, the mechanism by which the infant offspring of immunised female mice are protected from intestinal colonisation with C. jejuni.

\section{Materials and methods}

\section{Vaccination}

The non-flagellate variant SF-2 (NCTC 11827; National Collection of Type Cultures, Colindale, London NW9 5HT) of $C$. jejuni strain 81116 (NCTC 11828) was used for the vaccine as previously described (Dolby and Newell, 1986). Briefly, the organisms were harvested from blood agar in phosphate-buffered saline (PBS), $p \mathrm{H}$ $7 \cdot 2$. The suspension was adjusted to 50 International Opacity Units and then heat-killed in a water bath at $62^{\circ} \mathrm{C}$ for $45 \mathrm{~min}$. Female BALB/c mice were vaccinated intraperitoneally four times at weekly intervals with $0.2 \mathrm{ml}$ of the vaccine and then mated. This regimen was previously found to give about $80 \%$ protection (Dolby and Newell, 1986).

\section{Fostering}

Conception was detected by the presence of vaginal plugs, and caesarian section was performed on some of 
the pregnant females 18 days later. Caesarian-delivered infants from vaccinated dams were placed immediately with non-vaccinated foster dams that had themselves just given birth. Infants born to non-vaccinated dams were placed with vaccinated dams within the first $24 \mathrm{~h}$ of life, and vice versa. In a separate set of experiments, some naturally born infants were fostered at the age of 4-5 days. A few naturally born infants of vaccinated and nonvaccinated dams were left with their own mothers as controls. For the sake of convenience the dams were usually allowed to suckle either their own offspring or fostered offspring, but not a mixture of both.

\section{Challenge}

The wild flagellate strain of $C$. jejuni strain 81116 , (NCTC 11828) was grown for $24 \mathrm{~h}$ on blood agar at $37^{\circ} \mathrm{C}$ in micro-aerophilic conditions. A suspension of the growth was made in Brucella Broth (Difco), containing Campylobacter Supplement SR 84 (Oxoid) and adjusted to 10 International Opacity Units. An equal volume of sterile skimmed milk was added and each infant mouse was fed orally from a plastic-tipped needle and syringe 4-5 days after birth with $0.025 \mathrm{ml}$ containing approximately $10^{7}$ viable organisms (Dolby and Newell, 1986).

\section{Degree of colonisation}

Infant mice were killed at intervals of up to one week after challenge. A segment (c. $5 \mathrm{mg}$ ) of the colon was removed and viable organisms were estimated as described previously (Dolby and Newell, 1986). These estimations were made on 2-3 mice/litter at 2-3 and 5-6 days after challenge. The two estimations were invariably similar and provided a confirmation of results within each litter. In the present study, protection of individual infants rather than of families was assessed, by applying the scheme used by Dolby and Newell (1986) for complete protection and expressing the results as percentages. The $\chi^{2}$ test was used for statistical evaluation. A $p$ value of $<0.05$ was considered significant.

\section{Collection of serum and milk}

Blood was collected from vaccinated and non-vaccinated dams 6-7 weeks after the final dose of vaccine (i.e., 3-4 weeks after birth of the young and 2-3 weeks after challenge). The dams were anaesthetised and bled out from the heart. Serum was separated, heated at $56^{\circ} \mathrm{C}$ for $30 \mathrm{~min}$ and stored at $4^{\circ} \mathrm{C}$.

Milk was collected from the stomachs of infant mice, killed about 7 days after birth (2-3 days after challenge), and stored at $-70^{\circ} \mathrm{C}$. It was thawed, homogenised in an equal volume of PBS and centrifuged at $12000 \mathrm{~g}$, and the supernate was collected for testing.

\section{Antibody determination by the enzyme-linked immunosorbent assay (ELISA)}

The concentration and Ig class of specific antibody in samples of serum and milk were measured. Strain 81116 cells, disrupted ultrasonically, were used to coat the wells (Newell, 1986), but the conjugate consisted of alkaline phosphatase and goat anti-mouse IgG or IgA (Sigma, Fancy Road, Poole, Dorset BH17 7NH). The substrate consisted of a tablet $(5 \mathrm{mg})$ of the disodium salt of $p$ nitrophenyl phosphate (Sigma) dissolved in $5 \mathrm{ml}$ of $10 \%$ diethanolamine buffer, $p \mathrm{H} 9.8$ (Don Whitley Scientific Ltd, Shipley, West Yorkshire BD17 5JS). The optical density was read on a micro ELISA reader at $490 \mathrm{~nm}$.

\section{Results}

In this series of experiments, the protection conferred by vaccinated dams on their own infants against intestinal colonisation by $C$. jejuni was $91 \%$ (table I).

Table I. C. jejuni infection in infant mice fostered within $24 \mathrm{~h}$ of birth

\begin{tabular}{lcc|c}
\hline \multicolumn{1}{c|}{$\begin{array}{c}\text { Infant mouse } \\
\text { group }\end{array}$} & $\begin{array}{c}\text { Number of } \\
\text { litters }\end{array}$ & $\begin{array}{c}\text { Number of } \\
\text { infants }\end{array}$ & $\begin{array}{c}\text { Percentage } \\
\text { protected }\end{array}$ \\
\hline I/U left with own dam & 11 & 37 & $0^{*}$ \\
I/V left with own dam & 10 & 23 & $91^{*}$ \\
I/V fostered by UD & 22 & 49 & 0 \\
I/U fostered by VD & 18 & 48 & $50 \dagger$ \\
\hline
\end{tabular}

$\mathrm{I} / \mathrm{U}=$ infants from unvaccinated dam (UD).

$\mathrm{I} / \mathrm{V}=$ infants from vaccinated dam (VD).

* Confirms the findings of Dolby and Newell (1986).

† A further $25 \%$ showed a $50-75 \%$ reduction in colonisation.

Failure of placental antibody or colostral antibody ingested during the first $24 \mathrm{~h}$ of life to protect against oral challenge

Initially, caesarian section was performed to ensure that mammary secretion from vaccinated dams was not taken by their own infants before they were transferred to unvaccinated foster mothers. The colonisation was compared with that of naturally born infants of vaccinated dams fostered within $24 \mathrm{~h}$ of birth by non-vaccinated dams. There was no protection in either group (fig. 1), indicating that neither placental antibody nor colostrum taken within the first $24 \mathrm{~h}$ of life by infants from vaccinated dams influenced the effects of a challenge given 4-5 days later. In the light of these findings the next experiments were performed with naturally born infants, transferred to foster dams within $24 \mathrm{~h}$ of birth.

\section{Protection of infant mice fostered within 24 h of birth}

The colonisation of naturally born offspring of vaccinated dams transferred within the first $24 \mathrm{~h}$ of 
a

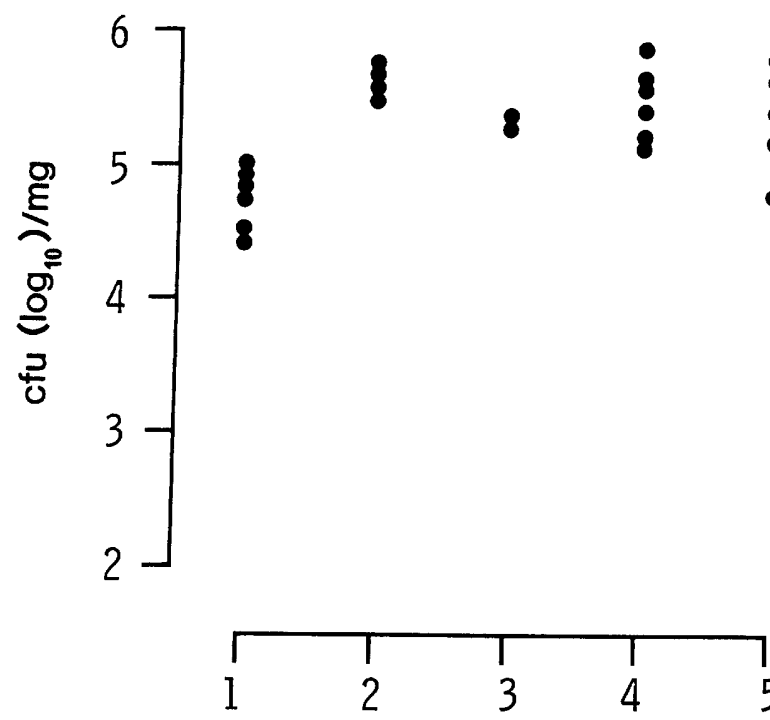

b

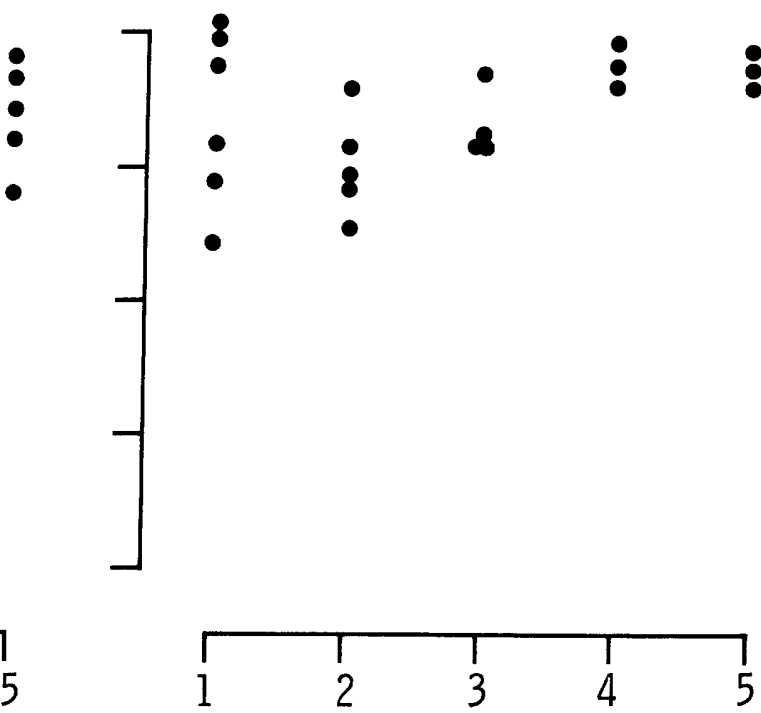

\section{Litters}

Fig. 1. The colonisation at 2-3 days after challenge of infants of vaccinated dams fostered on to non-vaccinated dams. (a) Caesariandelivered infants, fostered immediately. (b) Naturally delivered infants fostered within $24 \mathrm{~h}$. Each point represents one member of a 2-6 member litter. Viable counts are expressed as cfu/mg of mouse colon.

a

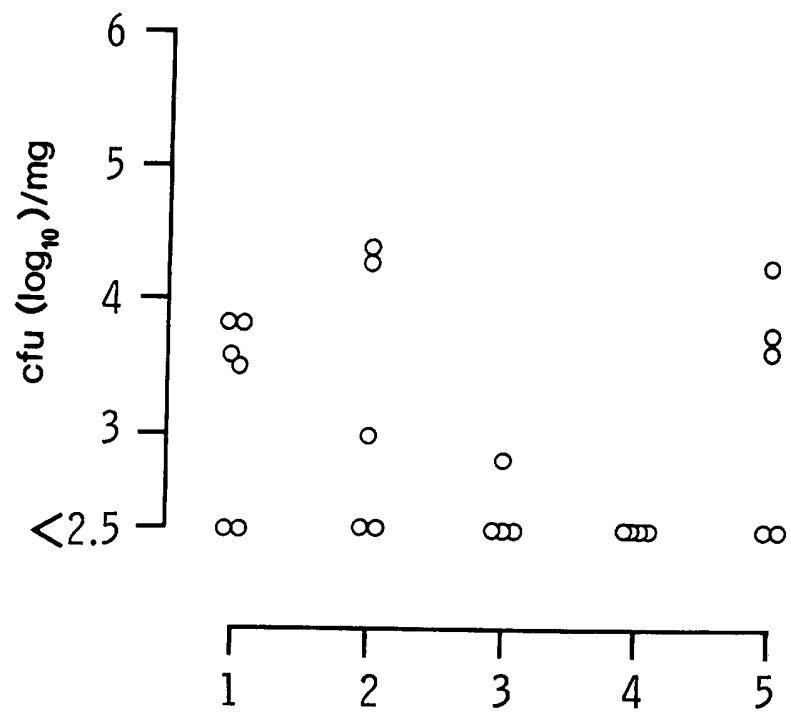

b
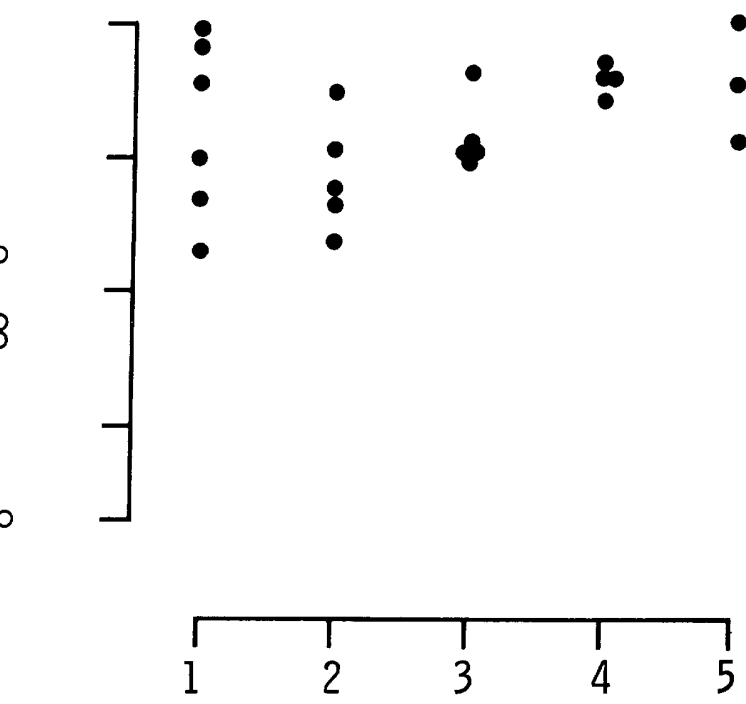

\section{Litters}

Fig. 2. The colonisation at 6 days after challenge of infants of vaccinated and non-vaccinated dams fostered within $24 \mathrm{~h}$ of delivery on to non-vaccinated and vaccinated dams respectively. (a) Vaccinated foster dams. (b) Non-vaccinated foster dams. Each point represents one member of a 2-6 member litter. Viable counts are expressed as cfu/mg of mouse colon. 
life to non-vaccinated dams, and vice versa, was next investigated. The degree of colonisation in 10 litters is given in fig. 2. Of 24 infants born to five non-vaccinated dams and transferred to vaccinated foster dams, 13 showed no sign of colonisation and the remaining 11 infants were colonised with no more than $10^{4 \cdot 5} \mathrm{cfu} / \mathrm{mg}$ of gut (fig. 2a). In contrast, almost all of the 23 infants born to five vaccinated dams and transferred to non-vaccinated foster dams were colonised with $>10^{4 \cdot 5} \mathrm{cfu} / \mathrm{mg}$ of gut, some with as many as $10^{6}$ (fig. 2b).

Vaccinated foster dams were, therefore, able to reduce significantly, by means of their mammary secretion, the ability of $C$. jejuni to colonise the infant mouse colon. However, they could protect only those infants that were with them at the time of challenge. Their own infants, transferred to nonvaccinated foster mothers within $24 \mathrm{~h}$ of birth, were not protected by the immune colostrum they had consumed. The summated results of all the experiments (61 litters) are given in table I. The proportion of infant mice completely protected by immune

' mammary secretion was greater among those left undisturbed with their own mothers $(91 \%)$ than among those transferred from unvaccinated mothers to vaccinated foster mothers within $24 \mathrm{~h}$ of birth $(50 \%)$. This difference $(\mathrm{p}<0.001)$ was reduced by the inclusion of partly protected mice (table I).

\section{The protective effect of immune mammary secretion taken up to the time of challenge}

The offspring of vaccinated females were left with their own mothers for the first 4 days of life until c. $1 \mathrm{~h}$ before challenge to allow any absorption of maternal immunoglobulins from the mammary secretion via the infant gut wall to take place. Immediately after challenge each litter was transferred to a non-vaccinated foster dam. Table II shows that immune mammary secretion taken up to the time of challenge now protected $10 \%$ of infant mice from colonisation; on the other hand, colostrum taken by control infants transferred to unimmunised dams within $24 \mathrm{~h}$ of birth gave no protection - a confirmation of all our previous results (table I and fig. 1). Table II also shows that $56 \%$ of infants from non-vaccinated mothers transferred at challenge to vaccinated dams were protected compared with $71 \%$ transferred within $24 \mathrm{~h}$ of birth.

These observations seem to suggest that protection was better the longer the infants were left with vaccinated dams before challenge. With the numbers of mice used, however, these small differences between the two groups of figures $(0 \%$ and $10 \%$;
Table II. $C$. jejuni infection in infant mice fostered 4 days after birth

\begin{tabular}{lccc|c}
\hline \multicolumn{1}{c|}{ Fostered } & & \\
$\begin{array}{c}\text { Infant mouse } \\
\text { group }\end{array}$ & $\begin{array}{c}\text { at age } \\
\text { (days) }\end{array}$ & $\begin{array}{c}\text { Number } \\
\text { of litters }\end{array}$ & $\begin{array}{c}\text { Number } \\
\text { of infants }\end{array}$ & $\begin{array}{c}\text { Percentage } \\
\text { protected }\end{array}$ \\
\hline $\begin{array}{l}\text { I/V fostered by } \\
\text { UD }\end{array}$ & $1^{*}$ & 4 & 18 & 0 \\
$\begin{array}{l}\text { I/U fostered by } \\
\text { VD }\end{array}$ & $1^{*}$ & 4 & 17 & 71 \\
$\begin{array}{l}\text { I/V fostered by } \\
\text { UD }\end{array}$ & 4 & 6 & 30 & $10 \dagger$ \\
$\begin{array}{l}\text { I/U fostered by } \\
\text { VD }\end{array}$ & 4 & 6 & 25 & $56 \S$ \\
\hline
\end{tabular}

* These mice are included for comparison, and to confirm earlier results (table I and fig. 1).

$\dagger$ An extra 7\% were partially protected.

$\S$ An extra $16 \%$ were partially protected.

Abbreviations as in table I.

$56 \%$ and $71 \%$ ) fall short of being statistically significant.

\section{Antibody assays (ELISA)}

High titres of campylobacter-specific IgG antibody were demonstrated in the serum $(162000$ $486000)$ and milk (2700-72900) of vaccinated dams. Generally, a high concentration of $\mathrm{IgG}$ antibody in the serum of a mouse was reflected in its milk, though at a slightly lower concentration. There was, however, very little IgA in either milk or serum. Non-vaccinated dams had no demonstrable campylobacter-specific IgG or IgA.

\section{Discussion}

In mice, maternal immunity is acquired via the placenta and colostrum (Fahey and Barth, 1965), but the trans-placental proportion is small (Brambell, 1966). Antibodies, mainly as IgG in colostrum and milk, may act locally in the gut or be absorbed (Halsey et al., 1982; Appleby and Catty, 1983). The relative importance of circulating and intestinal antibody in $C$. jejuni diarrhoea in man has not been established. In mice we could investigate only the prevention of colonisation and not the prevention of diarrhoea, from which mice rarely suffer.

Our experiments with infant mice show that immune mammary secretion protects strongly against intestinal colonisation by $C$. jejuni, in natural and fostered offspring, provided that it is taken at and after the time of challenge. Transplacental immunity plays no part.

From our experiments, it is difficult to attribute 
firmly any protective role to circulating IgG antibodies absorbed from milk in the gut. There was a suggestion, however, of a slight protective effect. This was similar to that achieved by injecting hyperimmune antiserum repeatedly into infant mice (Abimiku, unpublished experiments; Newell, 1986). This suggestion was evident in two observations. (1) The proportion of infants protected when left undisturbed with their vaccinated dams was larger $(91 \%)$ than that of infants fostered on to vaccinated dams $(50-75 \%)$; the difference in complete protection between the two groups was statistically significant $(\mathrm{p}<0.001)$. However, different feeding patterns in fostered and natural offspring might have produced quantitative differences in antibody transmission. (2) There was a slight protective effect $(10-17 \%)$ in infants left with their own vaccinated dams for 4-5 days before being challenged and fostered on to non-vaccinated dams but none in infants fostered $24 \mathrm{~h}$ after birth. In this instance the difference between the two groups was not statistically significant and the slight apparent protective effect might have been attributable either to circulating antibodies absorbed from the milk or to the residual milk antibody in the stomachs of infants fostered at the time of challenge on to non-vaccinated dams. The part played by mammary secretion from vaccinated

\section{REFERENCES}

Ahnen D J, Brown W R 1982 Campylobacter enteritis in immune-deficient patients. Annals of Internal Medicine 96 : 187-188.

Appleby P, Catty D 1983 Transmission of immunoglobulin to foetal and neonatal mice. Journal of Reproductive Immunology $5: 203-213$.

Brambell F W R 1966 The transmission of immunity from mother to young and the catabolism of immunoglobulins. Lancet 2: 1087-1093.

Butzler J-P, Skirrow M B 1979 Campylobacter enteritis. Clinics in Gastroenterology 8 : 737-765.

Dolby J M, Newell D G 1986 The protection of infant mice from colonization with Campylobacter jejuni by vaccination of the dams. Journal of Hygiene 96: 143-151.

Fahey J L, Barth W F 1965 The immunoglobulins of mice. 4. Serum immunoglobulin changes following birth. Proceedings of the Society for Experimental Biology and Medicine 118: $596-600$.

Fauchère J L, Véron M, Lellouch-Tubiana A, Pfister A 1985 Experimental infection of gnotobiotic mice with Campylobacter jejuni: colonisation of intestine and spread to lymphoid and reticuloendothelial organs. Journal of Medical Microbiology 20: 215-224.

Field L H, Underwood J L, Pope L M, Berry L J 1981 Intestinal colonization of neonatal animals by Campylobacter fetus subsp. jejuni. Infection and Immunity 33: 884-892.

Halsey J F, Mitchell C, Meyer R, Cebra J J 1982 Metabolism of dams in the prevention of colonisation by $C$. jejuni resembles that in rotavirus infection of neonatal mice (Sheridan et al., 1984).

We found high concentrations of IgG specific for $C$. jejuni in the milk and serum of vaccinated dams but little specific IgA antibody. Mice differ from most mammals in having a low concentration of IgA antibody in their milk during the first 4 days of lactation, but an increase thereafter has been reported (Halsey et al., 1982). Most of the milk in these experiments was collected 2-3 days after a challenge given 4-5 days after birth, and IgA antibodies should have been demonstrable if present. Assays were, however, made on unseparated immunoglobulins; this may have led to a blocking of the IgA assay by $\operatorname{IgG}$ antibody. On the other hand, the intraperitoneal vaccination of the dams probably stimulated a humoral IgG antibody response (Lange and Holmgren, 1978), which may well have influenced the Ig class in the milk (Parrot, 1979).

We thank Dr Diane Newell, Centre for Applied Microbiology and Research, Porton Down, for the strains of $C$. jejuni and for help with the ELISA; Drs Susan Stephens and S. P. Borriello of the Clinical Research Centre for helpful discussions; Miss Moira Hegan for supervising the caesarian sections and infant transfer; and $\mathrm{Mr}$ P. Hayes, Mr C. Windler and other members of the Animal House staff.

immunoglobulin A in lactating mice: origins of immunoglobulin A in milk. European Journal of Immunology 12: 107-112.

Kaldor J, Pritchard H, Serpell A, Metcalf W 1983 Serum antibodies in campylobacter enteritis. Journal of Clinical Microbiology 18: 1-4.

Klipstein F A, Engert R F, Short H, Schenk E A 1985 Pathogenic properties of Campylobacter jejuni: assay and correlation with clinical manifestations. Infection and Immunity 50: 4349.

Lange S, Holmgren J 1978 Protective antitoxic cholera immunity in mice: influence of route and number of immunisations and mode of action of protective antibodies. Acta Pathologica et Microbiologica Scandinavica Section C 86: 145-152.

Newell D G 1986 Monoclonal antibodies directed against the flagella of Campylobacter jejuni: production, characterization and lack of effect on the colonization of infant mice. Journal of Hygiene 96 : 131-141.

Newell D G, McBride H, Dolby J M 1985 Investigations on the role of flagella in the colonization of infant mice with Campylobacter jejuni and attachment of Campylobacter jejuni to human epithelial cell lines. Journal of Hygiene, 95 : 217-227.

Newell D G, Pearson A 1984 The invasion of epithelial cell lines and the intestinal epithelium of infant mice by Campylobacter jejuni/coli. Journal of Diarrhoeal Diseases Research 2: 1926.

Parrot D M V 1979 Source, identity and locomotor characteristics of lymphocyte populations migrating to mammary glands: 
problems and predictions. In: Ogra P L, Dayton D H (eds). Immunology of breast milk. Raven Press, New York, pp $131-157$

Sheridan J F, Smith C C, Manak M M, Aurelian L 1984 Prevention of rotavirus-induced diarrhea in neonatal mice born to dams immunized with empty capsids of simian rotavirus SA-11. Journal of Infectious Diseases 149: 434438.
Taylor N S, Ackerman J, Fox J G 1985 Adherence to tissue cultured cells of Campylobacter jejuni and C. coli from symptomatic and asymptomatic human and animal sources. In: Pearson A D et al. (eds) Campylobacter III, PHLS, London, $\mathrm{p} 134$.

Wenman W M et al. 1985 Antigenic analysis of Campylobacter flagellar protein and other proteins. Journal of Clinical Microbiology 21 : 106-112. 